\title{
Effects of EFL Learners' Perspectives on Online English Classes: Gender, Major, and Proficiency
}

\author{
Cha, Yoonjung ${ }^{1}$; Kim, Na Young ${ }^{2}$; Kim, Hea-Suk ${ }^{3}$
}

\begin{abstract}
This study explores the association between gender, major, language proficiency, and student perspectives toward an online educational setting. Participants included 366 university freshmen who attended ten general English courses in the spring semester of 2020. They took online courses featuring pre-recorded video lessons and synchronous classes via Zoom. They were divided by gender, by major into four groups, and by proficiency level totaling three groups to investigate whether there were significant differences between variables. The questionnaire was comprised of four different categories (closed-ended) and three open-ended items (benefits, drawbacks, and suggestions). According to the results of the questionnaire, gender and major had no effect on student perspectives toward online learning. However, statistically significant differences were found between the proficiency levels. Specifically, intermediate students are inclined to be more positive about online learning compared to beginners and advanced students. In conclusion, it can be noted that proficiency levels play an important part in student engagement and in attitudes toward online learning. Lastly, students mentioned that one of the advantages of online learning is students can repeatedly review online materials at their convenience, but identified non-immediate feedback, technical problems, and fewer opportunities for communication as disadvantages. Pedagogical implications and related future studies are suggested.
\end{abstract}

Keywords: online learning, gender, major, proficiency, student perspectives Applicable level: tertiary

\footnotetext{
${ }^{1}$ First author, Professor, Peace and Liberal Arts College, Hanshin University, 137 Hanshindae-gil, Osan-shi, Gyeonggi-do, 18101, Korea (E-mail: yjcha@hs.ac.kr)

${ }^{2}$ Corresponding author, Assistant professor, Dept. of General Education, Sehan University, 33 Sehandae-gil, Sinpyeong-myeon, Dangjin-si, Chungcheongnam-do, 31746, Korea (E-mail: nykim@sehan.ac.kr)

${ }^{3}$ Co-author, Associate professor, Seoul Women's University, 621 Hwarang-ro, Nowon-gu, Seoul, 01797, Korea (E-mail: shskim@swu.ac.kr)
}

Received: August 21, 2021 Copyright: C 2022 The Society for Teaching English through Media (STEM)

Revised: February 14, 2022 This is an open access article distributed under the terms of the Creative Commons Attribution

Accepted: February 22, 2022 Non-Commercial License (http://creativecommons.org/licenses/by-nc/4.0), which permits unrestricted non-commercial use, distribution, and reproduction in any medium, provided the original work is properly cited. 


\section{INTRODUCTION}

Due to the outbreak of Coronavirus (COVID-19), educational institutions have developed technical resources to provide their students with online learning material (Kaur, 2020). A wide range of online tools such as YouTube, Zoom, or PowerPoint have been used to suit the local context (Yi \& Jang, 2020). Teachers have changed their traditional teaching methods to utilize online learning systems (Hodges, Moore, Lockee, Trust, \& Bond, 2020). Particularly in language education fields, a variety of online learning applications have been adopted during the pandemic (Famularsih, 2020). In EFL settings, language classrooms have also been reshaped in many ways to conduct online classes (Kim, Cha, \& Kim, 2021).

Online learning can be influenced by various factors. Therefore, when a course is offered online, teachers are required to deal with individual features or differences that are likely to affect learning outcomes. It has been said that gender, major, and proficiency are the main factors that contribute to students' online learning (Liu, 2011). According to Liu and D'Andrea (2010), when it comes to an online class, it is worthwhile to examine the students' demographic data such as major and gender. Hsieh, Huang, and Wu (2017) additionally noted that proficiency can also be considered an important factor for successful online learning.

Language experts have also found that students have positive perspectives and similar points of view regarding gender, major, and proficiency differences. According to Kang (2015), knowing the effects of gender differences on language learning can pave the way to successful language learning. Differences in major are also seen as one of the major factors that affect language learning ( $\mathrm{Gu}, 2002)$. Hsieh et al. (2017) added that proficiency is also an important issue that should be addressed in language learning.

Interestingly, however, related studies of these factors have demonstrated no significant differences across gender, major, and proficiency (Balta \& Tzafilkou, 2019; Coca \& Slisko, 2013; Kaya \& Balta, 2015; Kim, 2019a; Liu, 2011; Liu \& Taylor, 2013; Somenarain, Akkaraju, \& Gharbaran, 2010; Wang, Aanesl, \& Gamnes, 2014). For example, scholars have found that students have a positive perspective of online learning regardless of major. In his study, Liu (2011) reported that the difference in major had no impact on students' preference for online learning, meaning that students' majors did not affect their perspective on online learning. In EFL settings, Balta and Tzafilkou (2019) also discovered that differences in their majors had minor effects on students' perspectives on online learning. Thus, the influence of a student's major was less critical than expected.

With regard to the gender differences in students' online learning preferences, Balta and Tzafilkou (2019) found no significant differences across different genders in EFL settings. Kaya and Balta (2015) also revealed the insignificant differences between male and female students regarding their attitudes toward online EFL learning. Especially in the Korean EFL context, Kim (2019a) discovered that both genders have positive perspectives of online English lessons. Based on these findings, it has been suggested that there is no need to consider gender differences in EFL online classes.

Regarding the proficiency issue, no differences were also witnessed in perspectives across different language proficiency levels (Balta \& Tzafilkou, 2019). Previous EFL studies have also shown that students feel positive towards online learning regardless of their language proficiency levels (Cakrawati, 2017; Somenarain et al., 2010; Yoon, 2020). Their findings revealed no significant differences in experience, satisfaction, and interaction across students' language proficiency. In Korea, Kim et al. (2021) also explored EFL students' perspectives on online English learning according to language proficiency levels and concluded that there was no proficiency difference in students' perspectives on EFL classrooms.

Although Liu (2011) stated that gender, major, and proficiency all contribute to students' online learning, empirical research on these factors has produced inconsistent results. Thus far, such claims have not been sufficiently substantiated in extant studies of EFL classroom settings (Hsieh et al., 2017). In particular, there remains a lack of research on the relationship between these human factors and English learning in Korea (Kang, 2015; Kim, 2019b). From this point of view, it is necessary to investigate students' perspectives on their online learning experiences in the Korean EFL context focusing on individual differences or features.

Previous scholars have emphasized that one of the most important aspects of online learning is students' perspectives on their learning experience (Somenarain et al., 2010). Sun (2011) also claimed that it is important to understand students' perspectives on online learning. What set this study apart from the previous research was the 
fact that human factors including gender, major, and proficiency were examined. Considering the increased demand for online learning during the pandemic, this study tries to determine students' perspectives on online learning. To sum up, the study examines Korean EFL students' perspectives on their English online learning experiences according to their gender, major, and proficiency. Four research questions were postulated as follows:

1. Are there any significant effects of gender on Korean EFL students' perspectives on English online learning?

2. Are there any significant effects of majors on Korean EFL students' perspectives on English online learning?

3. Are there any significant effects of proficiency level on Korean EFL students' perspectives on English online learning?

4. What are Korean EFL students' perspectives toward online English classes?

\section{LITERATURE REVIEW}

\section{Gender, Major, and Proficiency Issue in EFL Learning}

Different variables affect foreign language learning, and according to McNamara (1996), one of them is gender. As a matter of fact, in language learning, gender has been a controversial issue. Zoghi, Kazemi, and Kalani (2013) found that female students received higher marks than male students in a foreign language test. This was in line with the study of Voyer and Voyer (2014), suggesting that gender differences favor females in education fields and that there is a female advantage in learning. In EFL settings, Motallebzadeh and Nematizadeh (2011) also reported that female students outperformed their male counterparts in oral performance. However, other scholars have yielded opposite results regarding gender differences in foreign language learning. Hyde, Lindberg, Linn, Ellis, and Williams (2008) claimed that any gender difference gap is closing and disappearing. In EFL contexts, Kaya and Balta (2015) reported the insignificant differences between male and female EFL students, suggesting that there is no need to consider gender differences in EFL classes.

In the Korean EFL environment, there have likewise been studies on the gender issue. No significant gender difference has been found in Korea regarding EFL learning. Park (2001), for example, reported no gender difference in Korean students' strategy use. It was found that Korean male and female students used the same strategies for foreign language learning. A. J. Kim (2017) also witnessed that gender did not affect the students' strategy use in foreign language learning. In her study, no significant differences in affective factors were found depending on gender. Similarly, Bernat and Lloyd (2007) discovered that Korean male and female students held similar views on EFL learning regarding their beliefs, expectations, motivations, and perceptions. Ko (2018) also found no significant gender difference in students' anxiety regarding foreign language learning.

To provide insights into the gender difference in EFL learning, Kim (2019b) also investigated the effects of gender. What set her study apart from other studies was the fact that students' proficiency level was included. A total of 204 Korean students (100 male and 104 female) participated in the study and their proficiency level was determined by their OPIc test scores. After exploring the gender effects on EFL learning according to proficiency levels, she found that the effects of gender differences varied across proficiency levels. No gender difference was found at the novice and intermediate proficiency levels. However, a clear and statistically significant difference was found at the advanced proficiency level. In her study, advanced female students performed better than their male counterparts.

From the perception survey results, Kim (2019b) found some differences across gender and proficiency. Female students in her study felt more nervous about English learning, regardless of their language proficiency. Although both genders at all proficiency levels became motivated to learn English after taking the class, the interview results revealed that the female students focused more on outer motivation than inner motivation while male students did the opposite. Interestingly, an advanced-level male student responded that he focused on social factors when learning English as a foreign language. It was important for him to study the same language with his friends. 
Differences in major are also seen as the main factors that affect language learning. Gu (2002) investigated the effects of gender and major on EFL learning. He found that female students significantly performed better than male students in both a vocabulary and general proficiency test. In his study, females also used more vocabulary learning strategies, which was found to be correlated with success in their EFL learning. Regarding the issue of university major, art students significantly outperformed science students in the general proficiency test, and strategy differences were found between arts and science majors. However, it was found to be a less important background factor when compared to gender.

When it comes to language learning, human factors are important issues. Students have different demographic data such as major and gender, diverse knowledge backgrounds, various goals, and a range of learning needs and styles with different levels of motivation. They also have mixed language abilities. According to Hsieh et al. (2017), proficiency is also an important issue that should be addressed in language learning. However, most language teachers face the challenge of teaching in the same classrooms combining students at different language proficiency levels. The proficiency issue has not been reflected appropriately in current classroom settings. As Wauters, Desmet, and Van Den Noortgate (2010) pointed out, conventional classrooms still prevail with a static, one-size-fits-all instructional model that requires all students to learn "the same information in the same structure using the same interface" (p. 549). Taking all this into consideration, individualized instruction is one of the biggest challenges in language classrooms (Webb \& Doman, 2016).

\section{Online Learning}

Online EFL learning enables individualized instruction by allowing teachers to teach students with different backgrounds like language abilities and learning achievements (Soliman, 2016). While the teachers can reach each student and give them immediate feedback in class, the online setting allows students to learn a foreign language at their own pace regardless of time and place. The students become autonomous through online learning by learning by themselves (Eneau \& Develotte, 2012). Consequently, online learning can develop EFL students' learner autonomy, improve their learning attitudes as well as participation levels, and increase their confidence and commitment levels (Kim \& Yoon, 2021). These can be effective teaching methods to enhance learning outcomes (Cha, 2018; Fatemi Jahromi \& Salimi, 2013; H.-S. Kim, 2017; Kim, 2018; Kim et al., 2021).

Online learning systems refer to web-based software to distribute, track, and manage courses over the Internet (Keis, Grab, Schneider, \& Ochsner, 2017). They use advanced technology to design and deliver the learning content. Teachers are unphysically present in virtual classes and create a supporting and comfortable atmosphere for students (Joshua, 2020). According to Mukhtar, Javed, Arooj, and Sethi (2020), online learning is a flexible method for teaching and learning as it helps distance learning with easy administration and accessibility with less use of resources and time, and this flexibility over face-to-face class has been reported in previous research as well (Keis et al., 2017).

Online learning modalities are also effective for teaching and learning as the two-way communication between students and teachers is facilitated with the implementation of advancements in technology (Thanji \& Vasantha, 2016). They use the Internet to communicate virtually during the learning process. Features in online learning such as web boards, chat rooms, discussion forums, and surveys allow the students and teachers to share course content and to communicate online. As Mukhtar et al. (2020) put it, these are convenient and productive ways to achieve learning goals.

All learning subjects including English can be taught online. According to Perveen (2016), online learning is an ideal medium for English language learning since it has the potential to utilize multiple teaching methods, learning styles, and strategies. Students have also perceived that online English learning helps them to practice and acquire new language skills (Cakrawati, 2017). Particularly, among higher education institutions, online learning has become a trend as an alternative approach in the teaching and learning process (Famularsih, 2020). Over the last decade, the Internet has made a huge impact on higher education, allowing the phenomenal growth of online education (Somenarain et al., 2010). It has been a solution to overcome physical distance, bringing students closer by enabling them to carry out projects together online (Haron, Yasmin, \& Ibrahim, 2015). 
However, online learning also has some pitfalls. An online class is where teachers and students are separated geographically. This results in decreased interaction with teachers in online learning (Adnan \& Anwar, 2020). Furthermore, there is a lack of students' feedback regarding their understanding of the subject. In addition, the students never see their fellows in person, only communicating with each other online. The real-time sharing of knowledge, information, and ideas is also missing in the digital learning world (Britt, 2006). Due to the lack of conventional classroom socialization, virtual classes cannot be of interest to tactile learners.

Hands-on sessions such as laboratory and clinical teaching can also be disrupted in online learning environments. Moreover, Internet connectivity is a major issue affecting learning through online modalities. Although simply improving internet connection would help resolve this (Mukhtar et al., 2020), for those living in rural areas or developing countries, the lack of fast and affordable Internet connections still hinders the process of online learning (Zhong, 2020). Therefore, the government should take immediate measures while telecommunication companies invest in expanding their advanced services across the country.

As online education is evolving, questions have been raised to find effective teaching and learning methods. Studies on online education have shifted the focus from technology itself to its impacts on students (Bangert, 2006). According to Somenarain et al. (2010), one of the most important aspects of online learning is to understand students' perspectives on their learning experience. Therefore, this study explores online learning focusing on students' perspectives.

\section{METHOD}

\section{Participants}

The study examined how gender, majors, and proficiency can be an affective factor in terms of students' perspectives toward online English classes. The study was conducted in the spring semester of 2020. The participants of the study included 336 university students from 10 different classes, but they registered for two different types of courses: TOEIC-based General English and Practical English. Although the title of the classes was different, the content of both classes was almost the same, and the focus skill was listening and reading.

TABLE 1

Participants' Demographic Information

\begin{tabular}{clcc}
\hline Factors & Subfactors & $N$ & $\%$ \\
\hline \multirow{2}{*}{ Gender } & Male & 218 & 64.9 \\
& Female & 118 & 35.1 \\
\hline \multirow{2}{*}{ Major } & Department of Social Sciences & 11 & 3.3 \\
& Department of Humanities & 60 & 17.9 \\
& Department of Science \& Engineering & 158 & 47.0 \\
& Department of Arts \& Music & 107 & 31.8 \\
\hline \multirow{2}{*}{ Proficiency } & Beginner & 178 & 53.0 \\
& Intermediate & 126 & 37.5 \\
& Advanced & 32 & 9.5 \\
\hline
\end{tabular}

The participants' demographic information was demonstrated in Table 1. The basic data collected via questionnaire at the end of the semester were categorized by gender, major, and proficiency. In terms of gender, there were 218 males (64.9\%) and 118 females (35.1\%). Their majors were divided into four different departments: 11 students (3.3\%) from the Department of Social Sciences, 60 students (17.9\%) from the Department of Humanities, 158 students (47.0\%) from the Department of Science and Engineering, and 107 students (31.8\%) from the Department of Arts and Music. Lastly, participants' proficiency was divided into three levels: 178 students (53.0\%) comprised the beginner level, 126 students (37.5\%) the intermediate, and 32 students $(9.5 \%)$ the advanced level. The proficiency levels of students were determined by the English level each student achieved during the Korean college entrance 
exam. The advanced students scored more than $80 \%$ (Grades 1-2) out of $100 \%$, the intermediate students 60 to 80 (Grades 3-4), and the beginner level scored less than 60 (Grades 5-9).

\section{Teaching Procedures and Instruments}

In the spring semester of 2020, due to the COVID-19 pandemic, most universities in Korea had to prepare for online classes. Both students and teachers had a difficult time adjusting to the new medium of classes. This particular university made use of three different types of class methods during the semester.

At the beginning of the semester, the classes were carried out by uploading pre-recorded videos for students to watch for six-weeks. The instructor made two twenty-five-minute videos per week. Then, students would schedule their own access to the class materials for a given time. The next six-week period used Zoom, a synchronous online class, with two 50-minute classes per week. The final method was for students to come to school for offline classes to take the examination. Before the semester ended, the questionnaire made using Google form was sent via the mobile message during the class period. The instructor provided specific instructions on how to respond to the online questionnaire. It took about 15 minutes.

The instrument developed by Shin (2003) and Swan (2003) to measure the satisfaction of cyber college students was modified and supplemented to suit this study. The questionnaire consisted of four areas asking about overall satisfaction, sense of achievement, willingness to study online, and teacher variables. Thus, the online questionnaire consisted of 30 closed-ended statements and three open-ended questions. The closed-ended statements included basic information as well as 26 items about students' and teachers' variables in relation to the online English classes.

The demographic information was composed of their majors, English proficiency, computer skills, the number of online English classes they were taking, and others. Twenty-six items were divided into two sections: sixteen items for student variables, and ten items for teacher variables. Then, sixteen items were classified into three: satisfaction with online classes (five items), preference for online study (six items), and willingness to study online (five items). A six-point Likert scale ( 1 = strongly disagree, $2=$ disagree, $3=$ somewhat disagree, $4=$ somewhat agree, $5=$ agree, $6=$ strongly agree) was used for this questionnaire. The reliability of the question items was tested using Chronbach's alpha. The Cronbach's alpha coefficients were .961 for the satisfaction with online classes, .922 for preference for online study, .924 for willingness to study online, and .960 for teacher variables. The results were, therefore, indicative of the internal consistency of the questionnaire items. Finally, three open-ended questions about benefits, drawbacks, and suggestions regarding online learning were added at the end of the questionnaire.

The questionnaire consists of 63 questions with 7 scales that were used to identify internal consistency. The preliminary analysis of the reliability analysis resulted in strong associations (greater than 0.6) for all variables.

\section{Data Analysis}

Participants submitted their questionnaires via Google form. To answer the research questions, quantitative and qualitative data were gathered to analyze survey responses. The data were analyzed by SPSS 23.0. Specifically, to compare differences among gender, major, and proficiency, independent $t$-tests, one-way ANOVAs, and a subsequent Post Hoc analysis were performed. The $t$-test analysis was used to investigate the differences between student attitudes and perspectives toward online English classes in terms of gender. For the second and third research questions, analysis of variance (ANOVA) was used to determine whether there were any significant differences among majors and proficiency levels. Then, Scheffe's post-hoc tests were carried out to determine whether there was a difference between the mean of pairs. In the last research question, data from three open-ended questions were analyzed. Keywords identified in the students' answers were classified into the same categories by three researchers. That is to say, all the participants shared their ideas about the benefits, and drawbacks of, and suggestions for online English classes. Responses were categorized into keywords and calculated by frequency and percentage. 


\section{RESULTS}

\section{Differences in Students' Perspectives Toward Online Classes Between Genders}

This section explores the differences in terms of students' perspectives toward online classes between groups. To do the comparison, the means of student perspectives across the different genders, majors, and proficiency levels were calculated. Included among the sub-categories dealing with student perspectives were: satisfaction with online classes (5 items), preference toward online classes (6 items), willingness to study online (5 items), and teacher variables (10 items). Teacher variables included to items on various class activities, instant feedback, the interaction between peers or between teacher and students, time management, and class management. Concerning the three research questions, if there were any significant differences between variables in terms of students' perspectives toward online classes, an independent $t$-test and one-way ANOVA for mean differences were conducted.

\section{TABLE 2}

Gender Differences in Terms of Students' Perspectives Toward Online Classes

\begin{tabular}{|c|c|c|c|c|c|}
\hline & Gender & $M$ & $S D$ & $t$ & $p$ \\
\hline \multirow{2}{*}{ Student Satisfaction } & Male & 18.115 & 6.757 & \multirow{2}{*}{-1.313} & \multirow{2}{*}{.190} \\
\hline & Female & 19.119 & 6.570 & & \\
\hline \multirow{2}{*}{ Student Preference } & Male & 22.202 & 7.506 & \multirow{2}{*}{-1.154} & \multirow{2}{*}{.249} \\
\hline & Female & 23.153 & 6.626 & & \\
\hline \multirow{2}{*}{ Student Willingness } & Male & 20.041 & 5.830 & \multirow{2}{*}{-1.041} & \multirow{2}{*}{.299} \\
\hline & Female & 20.737 & 5.884 & & \\
\hline \multirow{2}{*}{ Teacher Variables } & Male & 39.913 & 10.693 & \multirow{2}{*}{-.680} & \multirow{2}{*}{.497} \\
\hline & Female & 40.746 & 10.751 & & \\
\hline
\end{tabular}

Number of Male Students $=218 ;$ Female Students $=118$

The results of independent $t$-tests indicated that there were no significant differences between genders as shown in Table 2. For students'satisfaction, the means for male and female groups were $18.115(S D=6.757)$, and 19.119 ( $S D$ $=6.570)$, respectively. As for student preference, the mean for males was $22.202(S D=7.506)$ and $23.153(S D=$ 6.626) for females. Concerning student willingness to study online, the mean for males was $20.041(S D=5.830)$ compared with $20.737(S D=5.884)$, showing that there were no statistically significant differences $(p<.05)$. For teacher variables, the mean in the male group was 39.913 while that in the female group was 40.746 . There were no noticeable mean differences between the two groups $(t=-.680, p=.497)$, indicating that all students showed similar perspectives toward online activities.

As seen in Table 2, the result for the student perspectives between genders indicated that there were no noticeable differences. In other words, male and female students did not show any significant differences toward online English classes. Although statistically significant differences were not observed between male and female students, some interesting results were found. In general, the female students showed more positive views to learning English online than male students did.

This is in line with the findings of previous studies (Balta \& Tzafilkou, 2019; Kaya \& Balta, 2015; Liu, 2011) that the difference in gender had no effect on students' online learning. However, the finding is somewhat consistent with the previous research that female students showed more positive perspectives regarding learning English online (Voyer \& Voyer, 2014). While insignificant differences between genders were revealed regarding their attitudes and perspectives toward online learning, female students scored higher means than male students toward online English classes. Thus, it appears that careful consideration of gender differences should be applied in online EFL classes.

\section{Differences in Students' Perspectives Toward Online Classes Between Majors}

Students whose majors were management, economics, social welfare, and communication were included in the Department of Social Studies. Those who studied foreign languages, history, and philosophy were incorporated into the Department of Humanities. In addition, students who majored in engineering, technology, computer science, and 
chemistry were included in the Department of Science and Engineering, while those who studied arts, design, music, and physical education were incorporated into the Department of Arts and Music.

The means and standard deviations for student perspectives toward online classes computed for major groups are shown in Table 3. The findings of ANOVA demonstrated that majors had no significant effects on students' perspectives toward English online classes.

TABLE 3

Major Differences in Terms of Students' Perspectives Toward Online Classes

\begin{tabular}{|c|c|c|c|c|c|}
\hline & Major & $M$ & $S D$ & $F$ & $p$ \\
\hline \multirow{4}{*}{ Student Satisfaction } & Department of Social Sciences & 18.364 & 7.540 & \multirow{4}{*}{2.063} & \multirow{4}{*}{.105} \\
\hline & Department of Humanities & 19.317 & 6.606 & & \\
\hline & Department of Science and Engineering & 17.525 & 6.916 & & \\
\hline & Department of Arts and Music & 19.393 & 6.225 & & \\
\hline \multirow{4}{*}{ Student Preference } & Department of Social Sciences & 20.909 & 7.956 & \multirow{4}{*}{2.581} & \multirow{4}{*}{.053} \\
\hline & Department of Humanities & 23.500 & 7.303 & & \\
\hline & Department of Science and Engineering & 21.500 & 7.418 & & \\
\hline & Department of Arts and Music & 23.692 & 6.598 & & \\
\hline \multirow{4}{*}{ Student Willingness } & Department of Social Sciences & 19.727 & 5.551 & \multirow{4}{*}{2.272} & \multirow{4}{*}{.080} \\
\hline & Department of Humanities & 21.717 & 5.779 & & \\
\hline & Department of Science and Engineering & 19.531 & 5.931 & & \\
\hline & Department of Arts and Music & 20.654 & 5.690 & & \\
\hline \multirow{4}{*}{ Teacher variables } & Department of Social Sciences & 39.909 & 13.678 & \multirow{4}{*}{1.251} & \multirow{4}{*}{.291} \\
\hline & Department of Humanities & 41.467 & 10.992 & & \\
\hline & Department of Science and Engineering & 39.038 & 10.833 & & \\
\hline & Department of Arts and Music & 41.252 & 9.970 & & \\
\hline
\end{tabular}

Number of Department of Social Sciences $=11$; Department of Humanities = 60; Department of Science \& Engineering = 158; Department of Arts \& Music $=107$

The results suggested that all of the variables between the four groups were not statistically significant, as seen in Table 3. Specifically, there were no significant differences in student satisfaction $(p=.105)$, student preferences ( $p$ $=.053)$, student willingness $(p=.080)$ as well as teacher variables $(p=.291)$ between the four major groups.

However, the data from the Department of Humanities and the Department of Arts and Music were showing higher means of student satisfaction compared to other groups $(M=19.317, M=19.393$, respectively). Similarly, for those two major groups, the Department of Humanities and the Department of Arts and Music, student preference toward online learning scored the highest means $(M=23.500, M=23.692)$ followed by the Department of Science and Engineering and the Department of Humanities. Interestingly, the Department of Humanities group scored the highest in student willingness to study English online $(M=21.717)$. Similarly, for those who studied from the Department of Humanities and the Department of Arts and Music, students' perspectives toward online learning scored the highest in terms of teacher variables $(M=41.467, M=41.252)$.

Moreover, students who majored in the Department of Humanities and those who studied arts and music generally had more favorable perspectives on online classes in all four categories than did the other majors. The results are not consistent with previous research that major as a variable had no effect on student preference for online learning (Liu, 2011).

As for the student willingness to study English online, the results aligned with those of the previous category. The students studying arts and music were more positive about studying online than those studying science and engineering. It can be assumed that the students majoring in literature and languages had more willingness and involvement in learning online than those majoring in science and engineering. These findings were similar to the previous work (Gu, 2002). However, in his study, arts students significantly performed better than science students in the language proficiency test. Although it was found to be a less important factor compared to gender, it seemed that there existed a major difference in language learning.

Furthermore, the current findings did not show that there was any statistical significance by the major in terms of teacher variables. These findings support the findings of the previous work (Liu, 2011) that students have positive perceptions of online learning regardless of major. He reported that the difference in major had no significant impact 
on students' perspectives on online learning. That is, the differences in major might not affect students' online learning. In EFL settings, Balta and Tzafilkou (2019) concluded that differences in major have only minor effects on students' perspectives in terms of online learning. In other words, the influence of their major was less critical than expected.

\section{Differences in Students' Perspectives Toward Online Classes Between Proficiency Levels}

To ascertain the answers to the third research question, whether there were any significant differences between language proficiency in terms of students' perspectives toward online classes, a one-way ANOVA was conducted on the students' perspectives, using proficiency levels as the independent variable. Table 4 shows the mean differences and standard deviations of the students' perspectives between the three proficiency level groups and also presents the results of the one-way ANOVA for mean differences.

TABLE 4

Proficiency Differences in Terms of Students' Perspectives Toward Online Classes

\begin{tabular}{|c|c|c|c|c|c|}
\hline & Proficiency & $M$ & $S D$ & $F$ & $p$ \\
\hline \multirow{3}{*}{ Student Satisfaction } & Beginner & 18.371 & 5.887 & \multirow{3}{*}{2.284} & \multirow{3}{*}{.103} \\
\hline & Intermediate & 19.143 & 7.456 & & \\
\hline & Advanced & 16.344 & 7.512 & & \\
\hline \multirow{3}{*}{ Student Preference } & Beginner & 22.348 & 6.354 & \multirow{3}{*}{1.822} & \multirow{3}{*}{.163} \\
\hline & Intermediate & 23.278 & 7.654 & & \\
\hline & Advanced & 20.656 & 9.458 & & \\
\hline \multirow{3}{*}{ Student Willingness } & Beginner & 19.747 & 5.199 & \multirow{3}{*}{3.228} & \multirow{3}{*}{$.041^{*}$} \\
\hline & Intermediate & 21.310 & 6.221 & & \\
\hline & Advanced & 19.250 & 7.242 & & \\
\hline \multirow{3}{*}{ Teacher Variables } & Beginner & 39.337 & 10.059 & \multirow{3}{*}{2.781} & \multirow{3}{*}{.063} \\
\hline & Intermediate & 41.929 & 10.658 & & \\
\hline & Advanced & 38.250 & 13.503 & & \\
\hline
\end{tabular}

Number of beginner students $=178$; Intermediate students $=126$; Advanced students $=32$

${ }^{*} p<.05$

With respect to student satisfaction, there was no significant mean difference toward online classes $(F=2.284, p$ $=.103)$. For student satisfaction, the mean score in the beginner group was 18.371, 19.143 in the intermediate group, and 16.344 in the advanced group. The results suggest that the students from different proficiency groups who engaged in online classes did not show any different perspectives. Although no noticeable differences between the groups were found, results indicate that those who had high proficiency in English showed lower satisfaction toward online classes than the other groups.

The result proved that students, regardless of their language proficiency levels, have a good attitude toward online learning, which accords with the findings of previous EFL studies (Cakrawati, 2017; Kim et al., 2021; Somenarain et al., 2010; Yoon, 2020). However, high-proficiency learners showed noticeably lower means in attitude toward online learning compared to other groups. These results can be assumed to be a consequence of the fact that learners who are more advanced and more confident when communicating in English prefer face-to-face interaction.

As for student preference for online classes, the result revealed no statistically significant differences between the groups. To be specific, the mean scores in the beginner group was 22.348, 23.278 in the intermediate group, and 20.656 in the advanced group. The findings showed that there was not any significant difference between the mean scores $(F=1.822, p=.163)$. Concerning student willingness, findings show that there was a statistically significant mean difference between the three groups $(F=3.228, p=.041)$. Lastly, there were no noticeable differences in teacher variables $(F=2.781, p=.063)$.

Despite the fact that there were no distinguishable differences in all factors, a Scheffe's post hoc test was carried out to confirm whether there was a significant difference in each sub-factor by students' English proficiency levels. As shown in Table 5, there were mixed results between the groups. There were significant differences in student 
satisfaction between the intermediate and advanced groups $(M D=2.799, p=.035)$. In terms of student willingness, a statistically significant difference was found between the beginner and intermediate groups $(M D=-1.562, p=.022)$. For teacher variables, there was a significant mean difference between the beginner and intermediate groups $(M D=$ $-2.591, p=.037)$. However, there was no significant mean difference between the three groups in terms of student preference to online learning.

TABLE 5

Result of Scheffe's Post Hoc Test on Students' Proficiency

\begin{tabular}{llccc}
\hline & \multicolumn{1}{c}{ Proficiency } & $M D$ & $S E$ & $p$ \\
\hline \multirow{3}{*}{ Student Satisfaction } & Beginner < Intermediate & -.772 & .777 & .321 \\
& Intermediate > Advanced & 2.799 & 1.321 & $.035^{*}$ \\
& Advanced < Beginner & -2.027 & 1.281 & .115 \\
\hline \multirow{3}{*}{ Student Preference } & Beginner < Intermediate & -.929 & .837 & .268 \\
& Intermediate > Advanced & 2.621 & 1.424 & .067 \\
& Advanced < Beginner & -1.692 & 1.381 & .222 \\
\hline \multirow{3}{*}{ Student Willingness } & Beginner < Intermediate & -1.562 & .677 & $.022^{*}$ \\
& Intermediate > Advanced & 2.059 & 1.150 & .074 \\
& Advanced < Beginner & -.497 & 1.116 & .656 \\
\hline \multirow{3}{*}{ Teacher Variables } & Beginner < Intermediate & -2.591 & 1.240 & $.037^{*}$ \\
& Intermediate > Advanced & 3.679 & 2.108 & .082 \\
& Advanced < Beginner & -1.087 & 2.045 & .595 \\
\hline
\end{tabular}

${ }^{*} p<.05$

Therefore, the study observed that the intermediate group showed more positive views of student satisfaction and student willingness to learn than the beginner and advanced groups. The perspectives related to teacher variables, such as giving feedback, time and class management, and various activities, depended on student proficiency levels. This is inconsistent with the results of a previous study (Kim et al., 2021), in which EFL students did not differ significantly in their perspectives on online English learning by language proficiency. However, this study supports the findings of the previous study (Kim, 2019b) that clear and statistically significant differences were found depending on proficiency levels. From this, it can be concluded that it is important to consider the effects of language proficiency levels in online learning (Hsieh et al., 2017).

\section{Students' Perspectives Toward Online Classes}

The questionnaire included three open-ended questions about the benefits, drawbacks, and any suggestions for taking general English courses online. The researchers categorized students' responses by similarity, then transcribed them in English. Initially, student' responses were analyzed by gender, major, and level, but there was no reason to do so because the students' opinions were similar. As a result, their perspectives are summarized and presented all at once. Although 336 students submitted their questionnaires, some students did not write their opinions, which were listed as 'no response' in each table. Table 6 demonstrates the benefits of taking general English courses online.

One hundred and three students (30.7\%) mentioned that reviewing the class materials repetitively was most helpful when watching the videos (Lin, Hong, \& Lawrenz, 2012). In other words, replaying the videos was effective for those who lacked understanding, wanted to reflect on the content material, and missed critical points of the content. Sixtyfour students (19\%) commented that it was most convenient that they could control their study schedules (Murphy, Rodríguez-Manzanares, \& Barbour, 2011). For example, they could watch the class videos whenever they wanted. They did not have to be on time for classes. In addition, twenty-eight students (8.3\%) responded that it was convenient since they did not have to be conscious of other classmates. For instance, if they were in the classrooms together, they needed to think about their responses to the professors all the time. Also, they would feel embarrassed in class if they did not know the correct answers. Another twenty-eight students $(8.3 \%)$ indicated that the class content which was provided by professors was useful and satisfactory. Then, twenty-two students $(6.5 \%)$ commented that online classes especially watching videos for learning was efficient (Lin et al., 2012). Furthermore, twenty students (6.0\%) mentioned that there was no space constraint meaning they could stay home rather than commute. They could even 
listen to the lectures wherever they preferred. Other opinions included: "I improved my grammar (3.9\%)", "I could pause the class materials on videos and have enough time for note-taking (3.0\%)", and "the professor uploaded some useful class materials (1.5\%)."

While a lot of the categories were observed, most responses from this open-ended question were relevant to the benefits of online learning (repetition/review, time \& space availability, convenience, etc.) It seems to reflect the possibility that students with online experience may be able to enhance their grades and time management.

\section{TABLE 6}

Benefits of Taking General English Courses Online

\begin{tabular}{llcc}
\hline \multicolumn{1}{c}{ Category } & \multicolumn{1}{c}{ Excerpts } & $N$ & $\%$ \\
\hline 1 Repetition/Review & I could repeatedly listen to the part that I didn't understand. & 103 & 30.7 \\
2 Time (No time constraints) & I could listen to the lectures according to my own schedules. & 64 & 19.0 \\
3 Convenience & It was convenient when listening to lectures. & 28 & 8.3 \\
4 Class content & The class content was great. & 28 & 8.3 \\
5 Class methods & Videos were useful. & 22 & 6.5 \\
6 Space (No space constraints) & I could listen to the lectures at home. & 20 & 6.0 \\
7 Skills improvement & I was able to improve my listening and speaking skills. & 13 & 3.9 \\
8 Note-taking & I could stop the videos whenever I needed time to take notes. & 10 & 3.0 \\
9 Material & Looking at PPT materials were helpful when learning English. & 5 & 1.5 \\
10 Technology & Sound quality was okay. & 5 & 1.5 \\
11 Participation & I could easily participate in an online class. & 4 & 1.2 \\
12 Concentration & I could concentrate better in an online class. & 2 & 0.6 \\
13 No response & \multicolumn{1}{c}{ Total } & 32 & 9.5 \\
\hline & & 336 & 100 \\
\hline
\end{tabular}

TABLE 7

Drawbacks of Taking General English Courses Online

\begin{tabular}{|c|c|c|c|}
\hline Category & Excerpts & $N$ & $\%$ \\
\hline $1 \mathrm{Q} \& \mathrm{~A} /$ Feedback & Since class content was a video, immediate feedback was impossible. & 71 & 21.1 \\
\hline 2 Technology & The quality of sound and videos were not good enough. & 62 & 18.4 \\
\hline $\begin{array}{l}3 \text { Class methods \& } \\
\text { activities }\end{array}$ & $\begin{array}{l}\text { I was not used to online classes. There were not enough opportunities to } \\
\text { practice speaking English. }\end{array}$ & 37 & 11.0 \\
\hline 4 Concentration & It was difficult to concentrate on class contents for a long period of time. & 31 & 9.2 \\
\hline 5 Communication & I wished I had more communication with the professor. & 20 & 6.0 \\
\hline 6 Class content & It was difficult for me to figure out the content if I didn't understand. & 16 & 4.8 \\
\hline 7 Attitude & I had a tendency to postpone my studies. & 9 & 2.7 \\
\hline 8 Class material & I wanted to more class materials to review my studies. & 5 & 1.5 \\
\hline 9 Miscellaneous & There was a copyright problem for using a certain textbook. & 2 & 0.6 \\
\hline \multirow[t]{2}{*}{10 No response } & & 83 & 24.7 \\
\hline & Total & 336 & 100 \\
\hline
\end{tabular}

Regarding the drawbacks of online English classes, students' responses are shown in Table 7. Seventy-one (21.1\%) students responded that it was impossible to ask any questions or receive any immediate feedback from an instructor since the class materials were videos. Sixty-two students $(18.4 \%)$ commented that the quality of sound and videos did not meet their expectations. Since it was the first semester under COVID-19, both schools and teachers were not ready for systematic online classes. Particularly, teachers did not get used to making class materials for videos, and the school's system did not fully accommodate students' needs. Thirty-seven (11.0\%) students commented that they also needed time to adjust to the new method of online learning and they wanted to have a chance to practice their speaking skills in person. In addition, thirty-one students $(9.2 \%)$ answered that it was difficult for them to concentrate on the class materials since they had to watch videos for every class without any communication whatsoever (Somenarain et al., 2010). Moreover, twenty students (6.0\%) felt that no communication with the professor or fellow students might have been a critical factor for learning (Marble, Fulcher, \& Karel, 2016). Finally, other minor opinions were "It was difficult for me to understand the class material (4.8\%)," "Since I didn't have to watch the class videos on time, I usually put it off until the last minute (2.7\%)," and "I wish the professor would upload more class materials $(1.5 \%) . "$ 
TABLE 8

Suggestions on Future Online Classes

\begin{tabular}{|c|c|c|c|}
\hline Category & Excerpts & $N$ & $\%$ \\
\hline 1 Technology & School online system should be stabilized. & 61 & 18.1 \\
\hline 2 Communication & There should be better communication between students and professors. & 39 & 11.6 \\
\hline 3 Online classes & I want to have more online classes in the future especially Zoom classes. & 28 & 8.3 \\
\hline 4 Q\&A/Feedback & There should be a way for us to communicate with a professor. & 23 & 6.8 \\
\hline 5 Teaching methods & The quality of the classes should be improved. & 20 & 6.0 \\
\hline 6 Satisfaction & I am satisfied with my English classes. & 13 & 3.9 \\
\hline 7 Class materials & Uploading class materials are necessary. & 10 & 3.0 \\
\hline 8 Participation & I hope I can participate more in the class activities. & 7 & 2.1 \\
\hline 9 Concentration & I want to focus more, but it is difficult. & 6 & 1.8 \\
\hline 10 Miscellaneous & A copyright issue should be solved. & 6 & 1.8 \\
\hline \multirow[t]{2}{*}{11 No response } & & 123 & 36.6 \\
\hline & Total & 336 & 100 \\
\hline
\end{tabular}

The open-ended question in the questionnaires revealed that most students had difficulties in terms of immediate feedback, technology utilization, class activities, concentration, and communication. Thus, it is important for students to receive feedback, to be able to communicate online, and to find ways to help them concentrate when learning online.

Finally, the last open-ended question was to ask for any suggestions regarding how to improve the learning environment for online classes in the future. As revealed in Table 8, sixty-one students (18.1\%) pointed out that the online system should be stabilized to minimize inconveniences for the users (Mukhtar et al., 2020). Then, thirty-nine $(11.6 \%)$ students reported that interaction, that is, communication is critical for a better learning environment in English classes. Also, twenty-eight students $(8.3 \%)$ commented that despite the disadvantages they mentioned before, they still wanted to continue their online classes. Twenty-three students $(6.8 \%)$ believed that there should be some ways to communicate or receive feedback from an instructor. In addition, twenty students $(6.0 \%)$ urged the improvement of the quality of the class content and the provision of better explanations for future classes. Some minor opinions included: "I was satisfied with the present online classes (3.9\%)," "Uploading class materials can be helpful (3.0\%)," and "There should be some ways for students to participate more during the class (2.1\%)."

In a nutshell, although online learning has drawbacks, the students agreed that online learning is beneficial and convenient to learn a foreign language. In addition, they proposed the further stabilization and development of the quality of online systems as well as the quality of instruction. One possible option to improve communication skills may be to have students practice answering synchronous/asynchronous questions and to develop online activities to indulge in during classes.

\section{CONCLUSION}

The COVID-19 pandemic has compelled nearly all universities to transition to online education. The shift from traditional class to online education has gone relatively smoothly in Korea. However, online platforms and technology have not yet been equipped to offer online education as effectively as face-to-face classes. In addition, many university students have reported dissatisfaction compared to traditional education systems. With this concern, this study attempts to provide more insights into the relationship between gender, major, language proficiency, and students' perspectives toward online learning in an EFL context.

Analyzing the data from the questionnaire, the findings of the current study are as follows. First, gender did not play a significant role in student perspectives toward online learning. In other words, satisfaction with online English classes, willingness to learn online, preference for learning online, and teacher variables did not differ much depending on gender. Similar to a previous study (Kim, 2019b), however, this study found that female students showed higher means in each variable. That is, female students showed more positive perspectives toward learning English online, which was in line with the study of Voyer and Voyer (2014).

Second, the overall perspectives towards online classes did not differ significantly by major, but statistically, there 
were noticeable differences between the Department of Science and Engineering, and the Department of Arts and Music. Significant differences were also found between those studying literature and the humanities and those who studied science and engineering. These findings revealed that students majoring in literature and languages, as well as arts and music, had significantly more positive attitudes toward online learning. This finding supports the previous study (Balta \& Tzafilkou, 2019) that student satisfaction and willingness to study online has a relationship with students' majors. In addition, teacher variables such as class and time management, class activities, feedback, and interaction were affected by students' majors as well.

Third, intermediate students showed a significant difference in means in terms of student satisfaction, willingness to learn online English, and teacher variables when compared to beginner and advanced students. Specifically, intermediate level students showed higher means in student satisfaction than advanced level students and showed more willingness to study English online than the beginner students. For the teacher variables, there was a significant mean difference between the beginner and intermediate groups. However, no significant differences were found, regardless of preference, for online classes. As a result, all proficiency groups have a preference for online learning after experiencing it under COVID-19. This result accords with the findings of a prior study (Kim, 2019b), which demonstrated substantial and statistically significant differences in proficiency levels. However, this finding is not consistent with the result of a previous study (Kim et al., 2021) that EFL students' perspectives on online classes were not affected by their language proficiency levels. Based on the results of the current study, it is critical to think about the impacts of language skill levels in online learning (Hsieh et al., 2017).

Finally, students' perspectives toward online English classes were analyzed. Various benefits, drawbacks, and suggestions that students offered should be carefully considered for the future online learning environment. Although there were no noticeable variance of results connected with gender, major, and proficiency level, those variables can be an affective factor in learning languages, especially through online mediums. Moreover, comparing the changes in scores between the pre-and post-questionnaires to examine which factor is most influential would further provide significant insight.

In general, there were no differences in students' perspectives toward online learning based on gender and major. Learners appeared to prefer learning in an online environment during the COVID-19 pandemic. However, based on the results of the questionnaires, more teacher-student and student-student interactions are required. Furthermore, the role of teachers is valued because the quality of online learning cannot be guaranteed if the content and management of the class is poor, and students' interest and concentration may decrease as a result. This study attempted to emphasize the importance of taking into account individual needs in online education during the COVID-19 crisis, but it is believed that it should be integrated into all aspects of online learning, including learning material selection, online interaction, technical support, etc.

With the limitations of this study in mind, suggestions for future studies are presented below. Because the participants in the study were college students, the results of the current study cannot be generalized to all learners. Participants of different ages may have different results; therefore, future research is needed to examine which factors have the most impact on the online educational environment by age group. In addition, learner variables such as language learning aptitude, learning motivation, anxiety, strategy, and familiarity with technology should be considered in future studies. Lastly, since this study is not intended to investigate the impact of online learning on language skills, it is necessary to study the effects of online learning on language skills compared to face-to-face traditional learning.

\section{REFERENCES}

Adnan, M., \& Anwar, K. (2020). Online learning amid the COVID-19 pandemic: Students' perspectives. Online Submission, 2(1), 45-51. https://doi.org/10.33902/JPSP.2020261309

Balta, N., \& Tzafilkou, K. (2019). Using Socrative software for instant formative feedback in physics courses. Education and Information Technologies, 24(1), 307-323. https://doi.org/10.1007/s10639-018-9773-8

Bangert, A. W. (2006). The development of an instrument for assessing online teaching effectiveness. Journal of Educational Computing Research, 35(3), 227-244. https://doi.org/10.2190/b3xp-5k61-7q07-u443 
Bernat, E., \& Lloyd, R. (2007). Exploring the gender effect on EFL learners' beliefs about language learning. Australian Journal of Educational \& Developmental Psychology, 7, 79-91. Retrieved from https://www.newcastle.edu.au/_data/assets/pdf_file/0012/100362/v7-bernat_lloyd.pdf

Britt, R. (2006). Online education: A survey of faculty and students. Radiologic Technology, 77(3), 183-190.

Cakrawati, L. M. (2017). Students' perceptions on the use of online learning platforms in EFL classroom. ELT Tech: Journal of English Language Teaching and Technology, 1(1), 22-30. https://doi.org/10.17509/elt\%20tech.v1i1.9428

Cha, Y. (2018). Using a student response system (Socrative) as a prereading method in an EFL reading environment. STEM Journal, 19(2), 95-119. https://doi.org/10.16875/stem.2018.19.2.95

Coca, D. M., \& Slisko, J. (2013). Software Socrative and smartphones as tools for implementation of basic processes of active physics learning in classroom: An initial feasibility study with prospective teachers. European Journal of Physics Education, 4(2), 17-24. Retrieved from https://files.eric.ed.gov/fulltext/EJ1052308.pdf

Eneau, J., \& Develotte, C. (2012). Working together online to enhance learner autonomy: Analysis of learners' perceptions of their online learning experience. ReCALL, 24(1), 3-19. https://doi.org/10.1017/S0958344011000267

Famularsih, S. (2020). Students' experiences in using online learning applications due to COVID-19 in English classroom. Studies in Learning and Teaching, 1(2), 112-121. https://doi.org/10.46627/silet.v1i2.40

Fatemi Jahromi, S. A., \& Salimi, F. (2013). Exploring the human element of computer-assisted language learning: An Iranian context. Computer Assisted Language Learning, 26(2), 158-176. https://doi.org/10.1080/09588221.2011.643411

Gu, Y. (2002). Gender, academic major, and vocabulary learning strategies of Chinese EFL learners. RELC Journal, 33(1), 35-54. https://doi.org/10.1177/003368820203300102

Haron, N. N., Yasmin, H. Z., \& Ibrahim, N. A. (2015). E-learning as a platform to learn English among ESL learners: Benefits and barriers. In S. Mahani \& J. Haliza (Eds.), Research in language teaching and learning (pp. 79106). Malaysia: Penerbit UTM Press.

Hodges, C., Moore, S., Lockee, B., Trust, T., \& Bond, A. (2020). The difference between emergency remote teaching and online learning. Educause Review, 27, 1-12. Retrieved from https://er.educause.edu/articles/2020/3/thedifference-between-emergency-remote-teaching-and-online-learning

Hsieh, J. S. C., Huang, Y. M., \& Wu, W. C. V. (2017). Technological acceptance of LINE in flipped EFL oral training. Computers in Human Behavior, 70, 178-190. https://doi.org/10.1016/j.chb.2016.12.066

Hyde, J. S., Lindberg, S. M., Linn, M. C., Ellis, A. B., \& Williams, C. C. (2008). Gender similarities characterize math performance. Science, 321, 494-495. https://doi.org/10.1126/science.1160364

Joshua, S. (2020). Introduction to online teaching and learning. Retrieved from http://www.wlac.edu/online/documents/otl.pdf

Kang, D. (2015). The gender role in L2 motivations of Korean university students. Korean Journal of English Language and Linguistics, 15(2), 305-325. https://doi.org/10.15738/kjell.15.2.201506.305

Kaur, D. (2020). Post-positivist approach to factors that influence K-12 teachers' use of iPads and Chromebooks. International Journal of Technology in Education and Science, 4(1), 26-36. https://doi.org/10.46328/ijtes.v4i1.30

Kaya, A., \& Balta, N. (2015). Taking advantages of technologies: Using the Socrative in English language teaching classes. International Journal of Social Sciences and Educational Studies, 2(3), 4-12. Retrieved from https://ijsses.tiu.edu.iq/wp-content/uploads/2017/12/Taking-Advantages-of-Technologies-Using-theSocrative-in-English-Language-Teaching-Classes.pdf

Keis, O., Grab, C., Schneider, A., \& Öchsner, W. (2017). Online or face-to-face instruction? A qualitative study on the electrocardiogram course at the university of Ulm to examine why students choose a particular format. BMC Medical Education, 17(1), 1-8. https://doi.org/10.1186/s12909-017-1053-6

Kim, A.-J. (2017). Language learning styles and the use of language learning strategies of foreign language learners. Studies in Humanities, 52, 293-316. Retrieved from https://www.dbpia.co.kr/journal/articleDetail?nodeId=NODE07130915 
Kim, H.-S. (2017). A comparative study of English vocabulary learning between mobile application and vocabulary list. STEM Journal, 18(1), 183-206. https://doi.org/10.16875/stem.2017.18.1.183

Kim, H.-S., Cha, Y., \& Kim, N. Y. (2021). Students' perspectives on pre-recorded video lectures versus videoconferencing lectures in the untact era. Journal of Research in Curriculum \& Instruction, 25(2), 164-178. https://doi.org/10.24231/rici.2021.25.2.164

Kim, N. Y. (2018). Computer chat versus mobile chat: Effects of different chat tools on EFL speaking and writing. STEM Journal, 19(2), 145-167. https://doi.org/10.16875/stem.2018.19.2.145

Kim, N. Y. (2019a). Effects of gender difference on English learning with technology. Journal of the Korea AcademiaIndustrial Cooperation Society, 20(8), 403-416. https://doi.org/10.5762/KAIS.2019.20.8.403

Kim, N. Y. (2019b). A study on gender differences in Korean students' foreign language learning: Effects of gender on oral proficiency improvement across proficiency levels. Journal of Learner-Centered Curriculum and Instruction, 19(15), 233-261. https://doi.org/10.22251/jlcci.2019.19.15.233

Kim, N. Y., \& Yoon, S. Y. (2021). A comparative study on blended learning and flipped learning: EFL students' learner autonomy, independence, and attitudes. Korean Journal of English Language and Linguistics, 21, 171-188. https://doi.org/10.15738/KJELL.21..202103.171

Ko, Y. (2018). Practical implications for EFL students' foreign language anxiety in relation with gender and teachers. The Journal of Humanities and Social Science, 9(6), 471-486. https://doi.org/10.22143/hss21.9.6.33

Lin, H. S., Hong, Z. R., \& Lawrenz, F. (2012). Promoting and scaffolding argumentation through reflective $\begin{array}{lllll}\text { asynchronous discussions. Computers \& } & \text { Education, } & \text { 59(2), }\end{array}$ https://doi.org/10.1016/j.compedu.2012.01.019

Liu, D. Y., \& Taylor, C. E. (2013). Engaging students in large lectures of introductory biology and molecular biology service courses using student response systems. In Proceedings of the Australian Conference on Science and Mathematics Education (pp. 154-162). Australian National University, Australia. Retrieved from https://openjournals.library.sydney.edu.au/index.php/IISME/article/view/7074/7585

Liu, L. (2011). Factors influencing students' preference to online learning: Development of an initial propensity model. International Journal of Technology in Teaching and Learning, 7(2), 93-108. Retrieved from https://sicet.org/main/wp-content/uploads/2016/11/ijttl-11-02-1_Liu.pdf

Liu, L., \& D'Andrea, L. (2010). Initial stages to create online graduate communities: Assessment and development. In V. Wang (Ed.), Encyclopedia of information communication technologies and adult education integration (pp. 911-926). Hershey, PA: IGI Global. https://doi.org/10.4018/978-1-61692-906-0

Marble, S. C., Fulcher, A., \& Karel, R. (2016). Developing an asynchronous online Tennessee master nursery producer program. Hort Technology, 26(5), 575-583. https://doi.org/10.21273/HORTTECH03341-16

McNamara, T. (1996). Measuring second language performance. London: Longman.

Motallebzadeh, K., \& Nematizadeh, S. (2011). Does gender play a role in assessment of oral proficiency? English Language Teaching, 4(4), 165-172. https://doi.org/10.5539/elt.v4n4p165

Mukhtar, K., Javed, K., Arooj, M., \& Sethi, A. (2020). Advantages, limitations and recommendations for online learning during COVID-19 pandemic era. Pakistan Journal of Medical Sciences, 36(COVID19-S4), 27-31. https://doi.org/10.12669/pjms.36.covid19-s4.2785

Murphy, E., Rodríguez-Manzanares, M. A., \& Barbour, M. (2011). Asynchronous and synchronous online teaching: Perspectives of Canadian high school distance education teachers. British Journal of Educational Technology, 42(4), 583-591. https://doi.org/10.1111/j.1467-8535.2010.01112.x

Park, J. E. (2001). Korean EFL learners' vocabulary learning strategies. English Teaching, 56(4), 3-30. Retrieved from http://journal.kate.or.kr/wp-content/uploads/2015/02/kate_56_4_1.pdf

Perveen, A. (2016). Synchronous and asynchronous e-language learning: A case study of virtual university of Pakistan. Open Praxis, 8(1), 21-39. https://doi.org/10.5944/openpraxis.8.1.212

Shin, N. (2003). Transactional presence as a critical predictor of success in distance learning. Distance Education, 24(1), 69-86. https://doi.org/10.1080/01587910303048

Soliman, N. A. (2016). Teaching English for academic purposes via the flipped learning approach. Procedia-Social and Behavioral Sciences, 232, 122-129. https://doi.org/10.1016/j.sbspro.2016.10.036 
Somenarain, L., Akkaraju, S., \& Gharbaran, R. (2010). Student perceptions and learning outcomes in asynchronous and synchronous online learning environments in a biology course. MERLOT Journal of Online Learning and Teaching, 6(2), 353-356. Retrieved from https://jolt.merlot.org/vol6no2/somenarain_0610.pdf

Sun, Y. H. S. (2011). Online language teaching: The pedagogical challenges. Knowledge Management \& E-Learning: An International Journal, 3, 428-447. https://doi.org/10.34105/j.kmel.2011.03.030

Swan, K. (2003). Developing social presence in online course discussions. In S. Naidu (Ed.), Learning and teaching with technology: Principles and practice (pp.147-164). London: Routledge.

Thanji, M., \& Vasantha, S. (2016). ICT factors influencing consumer adoption of e-commerce offerings for education. Indian Journal of Science and Technology, 9(32), 1-6. https://doi.org/10.17485/ijst/2016/v9i32/98650

Voyer, D., \& Voyer, S. D. (2014). Gender differences in scholastic achievement: A meta-analysis. Psychological Bulletin, 140(4), 1-31. https://doi.org/10.1037/a0036620

Wang, A. I., Aanesl, A. E., \& Gamnes, V. (2014). Three social classroom applications to improve student attitudes. Education Research International, 2014, 1-14. https://doi.org/10.1155/2014/259128

Wauters, K., Desmet, P., \& Van Den Noortgate, W. (2010). Adaptive item-based learning environments based on the item response theory: Possibilities and challenges. Journal of Computer Assisted Learning, 26(6), 549-562. https://doi.org/10.1111/j.1365-2729.2010.00368.x

Webb, M., \& Doman, E. (2016). Does the flipped classroom lead to increased gains on learning outcomes in ESL/EFL contexts? CATESOL Journal, 28(1), 39-67. Retrieved from https://files.eric.ed.gov/fulltext/EJ1111606.pdf

Yi, Y., \& Jang, J. (2020). Envisioning possibilities amid the COVID-19 pandemic: Implications from English language teaching in South Korea. TESOL Journal, 11(3), 1-5. https://doi.org/10.1002/tesj.543

Yoon, S. Y. (2020). Learning in emergent times: Learner experience and perspectives on ERT in university EFL Courses. Multimedia-Assisted Language Learning, 23(4), 109-131. https://doi.org/10.15702/mall2020.23.4.109

Zhong, R. (2020, March 17). The coronavirus exposes education's digital divide. The New York Times. Retrieved from https://www.nytimes.com/2020/03/17/technology/china-schools-coronavirus.html

Zoghi, M., Kazemi, S. A., \& Kalani, A. (2013). The effect of gender on language learning. Journal of Novel Applied Sciences, 2(49), 1124-1128. Retrieved from https://jnasci.org/wp-content/uploads/2013/12/1124-1128.pdf 